\title{
Diffuse plane xanthoma developing in association with prior monoclonal gammopathy
}

\author{
Lorena Falk, ${ }^{1}$ Delwyn Dyall-Smith, ${ }^{2}$ Wilhelm Stolz, ${ }^{1}$ Brigitte Coras-Stepanek ${ }^{1}$
}

'Department of Dermatology, Stadtisches Klinikum Muenchen GmbH, Muenchen, Germany ${ }^{2}$ Riverina Dermatology, Wagga Wagga, New South Wales, Australia

\section{Correspondence to Dr Delwyn Dyall-Smith, delwynds@gmail.com}

Accepted 31 January 2019

\section{DESCRIPTION}

Diffuse plane xanthoma is a rare form of non-Langerhans histiocytosis that typically presents as asymptomatic symmetric diffuse yellow macules and plaques on the periorbital skin, neck, upper trunk and flexures. Extracutaneous lesions may be noted in the oral cavity, eye, tendons, aortic valve, muscles and gastrointestinal system. ${ }^{1}$ It is strongly associated with haematological disorders. ${ }^{2}$

A 71-year-old man presented with a 9-month history of progressive asymptomatic yellow plaques symmetrically distributed around the periorbital skin, neck, torso and extremities (figure 1). There were no mucosal lesions. In addition, the recently described halo around cherry angiomas was clearly seen. ${ }^{3}$ His medical history included rheumatoid arthritis, anticardiolipin syndrome and post-surgical hypothyroidism, but significantly also monoclonal gammopathy of undetermined significance (MGUS) of IgG kappa light chain detected 4 years prior.

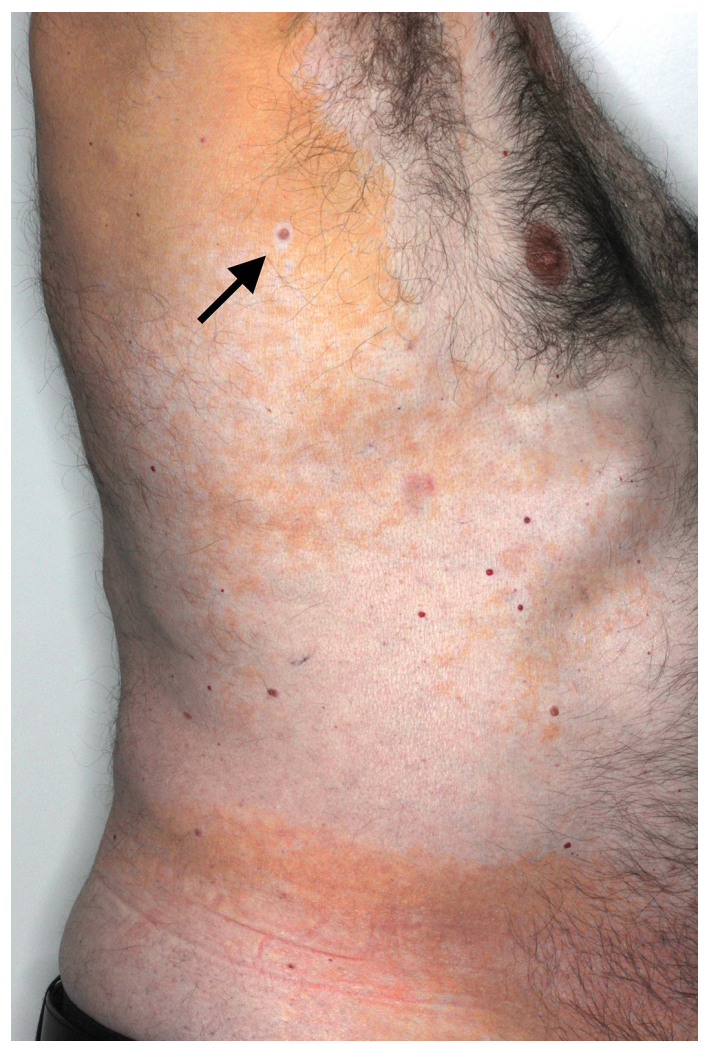

Figure 1 Yellow plaques in the right axilla and lower torso. The halo sign can be seen around cherry angiomas (arrow) within the yellow plaques.

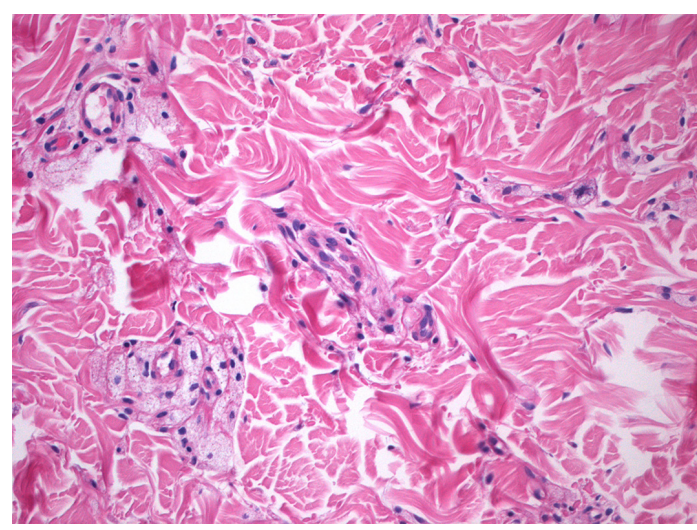

Figure 2 Skin biopsy demonstrated perivascular foamy CD68 positive cells.

An axillary skin biopsy was taken (figure 2). There were small aggregates of foam cells in the upper dermis. There was no fibrosis. Touton giant cells were seen but there were no other inflammatory cells.

Plasma lipids were normal. Further investigations including bone marrow biopsy and skeletal survey failed to demonstrate multiple myeloma.

A diagnosis of diffuse (normolipaemic) plane xanthomatosis associated with MGUS was made.

Diffuse plane xanthoma is usually reported in association with myelodysplastic conditions, as well as other haematological malignancies, but can rarely be idiopathic. ${ }^{2}$ In a large published series and review, multiple myeloma was associated in 48\%, with MGUS found in 41\%. An IgG kappa light chain was the most common monoclonal antibody reported. ${ }^{2}$ The skin signs usually precede the haematological diagnosis by several years so ongoing monitoring is recommended. ${ }^{4}$ Our patient was unusual as he had already been diagnosed with MGUS several years before his skin presentation. Importantly plasma lipid levels were normal.

In gammopathy-associated cases it is proposed the monoclonal IgG binds to circulating low-density lipoprotein which deposits around dermal blood vessels. The lipid droplet complex is then phagocytosed by macrophages resulting in the foamy appearance on histology, and the formation of xanthomas clinically. ${ }^{124}$

The differential diagnoses include hyperlipidaemic xanthomas and necrobiotic xanthogranuloma.

The prognosis depends on the underlying condition and treatment should be directed at that. Remission of the haematological condition has been reported to result in cutaneous improvement as well, with relapse indicated by recurrence of skin lesions. ${ }^{2}$ At this stage our patient does not require 
treatment for MGUS but is having regular haematological review for the development of multiple myeloma.

The presence of cutaneous xanthoma with normal plasma lipids requires further investigation and ongoing monitoring for an underlying haematological condition. ${ }^{2}$

\section{Learning points}

Cutaneous xanthoma should prompt assessment of plasma lipids.

- In the presence of normal plasma lipids further investigations are required for an underlying haematological condition, in particular monoclonal gammopathy of undetermined significance and multiple myeloma.

- Normolipaemic xanthoma may precede the haematological disorder by several years so ongoing monitoring is required.
Contributors LF, patient care and biopsy. DD-S, preparation and writing of manuscript, data interpretation. BC-S, patient care, pathology. WS, patient care, pathology.

Funding The authors have not declared a specific grant for this research from any funding agency in the public, commercial or not-for-profit sectors.

Competing interests None declared.

Patient consent for publication Not required.

Provenance and peer review Not commissioned; externally peer reviewed.

\section{REFERENCES}

1 Cohen Y, Elpern D. Diffuse normolipemic plane xanthoma associated with monoclonal gammopathy. Dermatol Pract Concept 2015;5:16.

2 Szalat R, Arnulf B, Karlin L, et al. Pathogenesis and treatment of xanthomatosis associated with monoclonal gammopathy. Blood 2011;118:3777-84.

3 Hida T, Takahashi H, Takada K, et al. Halo formations around senile hemangiomas in diffuse plane normolipemic xanthomatosis associated with monoclonal gammopathy. JAAD Case Rep 2018:4:1034-6.

4 Rosmaninho A, Fernandes I, Guimas A, et al. Diffuse plane xanthomatosis associated with monoclonal gammopathy. An Bras Dermatol 2011;86:50-2.

Copyright 2019 BMJ Publishing Group. All rights reserved. For permission to reuse any of this content visit https://www.bmj.com/company/products-services/rights-and-licensing/permissions/

BMJ Case Report Fellows may re-use this article for personal use and teaching without any further permission.

Become a Fellow of BMJ Case Reports today and you can:

- Submit as many cases as you like

- Enjoy fast sympathetic peer review and rapid publication of accepted articles

- Access all the published articles

Re-use any of the published material for personal use and teaching without further permission

For information on Institutional Fellowships contact consortiasales@bmjgroup.com

Visit casereports.bmj.com for more articles like this and to become a Fellow 